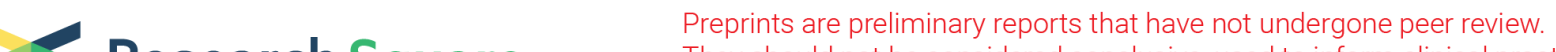 Research Square They should not be considered conclusive, used to inform clinical practice, or referenced by the media as validated information.
}

\section{Microbiome complexity in a NASA cleanroom facility affects planetary protection}

Ryan Hendrickson

Camilla Urbaniak

Jeremiah J. Minich

Heidi S. Aronson

Cameron Martino

Ramunas Stepanauskas

Rob Knight

Kasthuri Venkateswaran

\section{Video Byte}

Keywords: cleanroom, National Aeronautics and Space Administration, NASA, Spacecraft Assembly Facility, Jet Propulsion Laboratory, planetary protection, bioburden, Mars rover, bacteria, spore, non-sporeforming, microbe, NASA standard spore assay, NSA, 16S rRNA sequencing, Sanger sequencing, propidium monoazide, single-cell genomics, contamination, Microbiome

Posted Date: March 1st, 2022

DOI: https://doi.org/10.21203/rs.3.rs-1405898/v1

License: (c) (i) This work is licensed under a Creative Commons Attribution 4.0 International License. Read Full License 


\section{Abstract}

In the discipline of planetary protection, spacecraft are assembled in unique cleanrooms to prevent microbe transfer between planets. The cleanliness of these rooms has traditionally been assessed with the NASA standard spore assay (NSA), but advanced molecular techniques have revealed that this assay may be insufficient for contamination control. To learn more, researchers recently analyzed floor samples collected over 6 months from the Spacecraft Assembly Facility at NASA's Jet Propulsion Laboratory. The NSA coupled with Sanger sequencing identified 16 genera of bacteria, $97 \%$ of which were spore-formers, primarily Bacillus subtilis and Virgibacillus pantothenticus. However, 16S rRNA amplicon sequencing detected 51 additional bacterial genera. When viable and dead organisms were differentiated, amplicon sequencing identified 46 viable non-spore-forming genera ( $86 \%$ of bacteria) and 8 viable spore-forming genera ( $14 \%$ of bacteria). Sphingobium was most common across spatial sites, while Acinetobacter dominated over time. Single-cell genomics detected only 6 genera, the most abundant of which was Acinetobacter. Although further research is needed, the results show that bioburden estimates strongly depend on the chosen analysis method and suggest that the NSA should be combined with molecular methods to improve assessments for planetary protection. 